\title{
Strengthening and Sustaining of Industry- Academies-Government Partnership through Continuous Process Improvement
}

\author{
Dr.V.Thanikachalam ${ }^{1}$ \\ Executive Consultant in Engineering Education and HRD, \\ Chennai 600041 \\ vthani2025@gmail.com
}

\begin{abstract}
In this $21^{\text {st }}$ century many multinational corporations (MNCs) started moving to Asian countries both for design and manufacturing due to globalization of economy, raising middle class, desire to efficiently serve the local and export markets, and utilizing the availability of competent human capital. It is assessed that no industry would provide any donationto the institutes but ready to pay for the excellent services availed. From a comprehensive research, it is found that with the availability of large number of autonomous institutes, national institutes, and technical universities in India, there is a great opportunity to establish Industry-Academies-Government Partnership through executive education, research collaboration, product development and testing. Further, there is a need for dedicated centers of industry-academy-partnership with satellite units in the industrial hubs and corridors with enabling policies and empowered high performing faculty. The institutions have to extend support for mutual benefits so that the corporates can benefit from one-stop shopping and integrated research and development. The industries would support development and share the industry relevant outcome. The institutions have to charge the industry based on the realistic financial proposal based on the terms of reference (TOR). The institutes have to prepare business plans for various technical services like developing the executives and offer relevant services like testing, and extending the expertise. The institutes could develop
\end{abstract}

\footnotetext{
Dr.V.Thanikachalam ${ }^{1}$

Executive Consultant in Engineering Education and HRD, Chennai 600041

vthani2025@gmail.com
}

separate units for offering technical services through dedicated satellite centers in collaboration with networked institutes, if required. Such an approach would enable the rural institutes to overcome the difficulties due to far off location from the industrial hubs.

Keywords: Industry-Academies- Government-PartnershipContinuous Process Improvement-Satellite Centers in the Industrial Hubs- Corridors

\section{Introduction}

In the last twenty years, many developments have impacted engineering institutions due to globalization of Indian economy, entry of multinational companies (MNCs) and global outlook for engineering curricula. Considering the human resource requirements to meet the industrial developments,many self-financing institutions in engineering have emerged. The Ministry of Human Resource Development has assisted the government and government aided colleges through two World Bank assisted projects to improve the quality of technical education. However, there is a need for many more institution based reforms. A research has been initiated to identify the barriers that could be eliminated. The institutes need to implement strategic planning, improvements in the educational administrative process, decentralization, empowerment to the key faculty members who plan and develop the consultancy projects.Considering the needs of growing competent human capital, Ministry of Human Resource Development has established more Indian Institute of Technologies, Indian Institute of Managements, Indian Institutes of Information Technology, Indian Institute Information Technology and Design, Indian 
Institute of Science Education and Research and Schools Planning and Architecture. However, around 90\% of engineering education is offered by self-financing institutes. Due to the demand on the competent graduates, most of the newly established self-financing institutes could not attract high performing students. To bring success in the development of engineering institutes, the focus could be on the quality of the faculty, their competency in developing industry relevant programs. This can be facilitated through market driven consultancy and sponsored research.

\section{Impact of Globalization of Indian Economy}

Many industrial corridors have emerged for manufacturing automobiles, electronic components, electrical goods and other industrial products. Many MNCs also established design centers. The software companies have contributed to the Indian economy by their exports. All these demand high quality human resources and institutions which are capable of undertaking consultancy projects in product development, testing, and improving.

\section{Focus of MNCs and IDAs}

The MNCs would like to offer many programs on design related employee development to the engineering colleges, testing of materials, design of ancillary components, prototype developments, and research. Also many International Development Agencies (IDAs) have started offering project related faculty development to the engineering institutes and research programson the ongoing development oriented projects in India.

\section{Focus of Engineering Education}

Due to the globalization of engineering education, the focus of the institutes could be on developing high quality graduate and postgraduate programs with reasonable focus on the industry relevant educational program objectives, interdisciplinary and multidisciplinary courses with focus on key skills like design, manufacturing, and maintenance. The students need exposure to the modern industrial production processes and innovations.

\section{Strategic Planning of Engineering Institutes}

The institutes have to undertake realistic strategic planning to reach excellence, create appropriate vision to supply quality and competent human capital by employing competent faculty, undertaking consultancy programs which provide a proof of quality of the processes.

\section{Industry-Academies-Government-Partnership}

One method of quality of enhancement is due to forming Industry- Academies-Government Partnership and undertakes various outreach programs to bring two way transactions between the employer and supplier of human capital. Most of the times, the institutes fail to create networking among themselves. The synergy is lost and duplication of resources. Also the government has to be one of the elements in this consortium to facilitate and approve the innovations through councils and commissions. Otherwise there will be more barriers due to bureaucracy.

\section{Objectives of Research}

The major objectives of this research are:

- To assess the outcome of industry- AcademyGovernment-Partnership

- To identify the barriers for developing competent industry relevant human capital

- To suggest suitable changes in educational administration which will accelerate the growth of quality engineering programs and fostering competency in the graduates

\section{Population}

Faculty members with minimum ten years of experience and possessing master degrees in engineering/ technology from State Technical Universities, National Institutes of Technology, Private Deemed to be Universities, and Autonomous Colleges from the Southern Region were considered but ordinary self-financing collegesand newly started government colleges which are affiliated to state technical universities were not considered. All the professors with $\mathrm{Ph} . \mathrm{D}$ degrees in engineering were included in the research study.

\section{Sample}

The following purposive sample has been involved in this research.

\begin{tabular}{|l|l|l|}
\hline $\begin{array}{l}\text { Assistant } \\
\text { Professors }\end{array}$ & $\begin{array}{l}\text { Associate } \\
\text { Professors }\end{array}$ & Professors \\
\hline
\end{tabular}




\begin{tabular}{|l|l|l|}
\hline 72 & 53 & 21 \\
\hline
\end{tabular}

\section{Research Methodology}

Naturalistic Method has been adopted since, the focus is on the opinions from the faculty members on the performance and the difficulties faced in the Industry- AcademicsGovernment Partnership.

\section{Table-1 Presentation of the significant findings}

\begin{tabular}{|l|l|}
\hline Researchers & Contribution \\
\hline Emily Abbott et al (2011) & $\begin{array}{l}\text { Brought the essential elements of a successful twenty-first century corporate relation } \\
\text { programs }\end{array}$ \\
\hline Julio A Pertuze et al (2010) & $\begin{array}{l}\text { Described the following best practices for industry- University collaborations: Strategic } \\
\text { context, assess the in depth knowledge and technology needs of the industry, benefits to the } \\
\text { industry, long-term interest, and establishing strong communication linkages. }\end{array}$ \\
\hline $\begin{array}{l}\text { Katherine Chudoba, Mary } \\
\text { Beth Watson and Kevin } \\
\text { Crowston (2012) }\end{array}$ & $\begin{array}{l}\text { Brought out the innovation in Academic-Industry Partnerships: Measuring Challenges to } \\
\text { Effective Performance. }\end{array}$ \\
\hline $\begin{array}{l}\text { Mark L. Gorden } \\
\text { NACRO Writing Team and } \\
\text { Benchmarking Committee } \\
\text { (2011) }\end{array}$ & $\begin{array}{l}\text { Eniversity Controlled or Owned Technology: The State of Commercialization and } \\
\text { Recommendations to the Universities, }\end{array}$ \\
\hline Renu Khater (2013) & Forging Strategic Business Partnership to Develop the 21st Century Workforce \\
\hline Roger L Geiger & Corporate -Sponsored Research at Penn State \\
\hline $\begin{array}{l}\text { Senate Task Force on } \\
\text { University-Industry } \\
\text { Partnerships }\end{array}$ & $\begin{array}{l}\text { Principles and Guidelines for Large-Scale Collaborations between the University and } \\
\text { Industry, Government and Foundations }\end{array}$ \\
\hline Stephanie Bertels et al. & Challenges to Collaborative Research and Solutions for Addressing them \\
\hline UIDP Projects (2013) & Case Studies of High- Return University-Industry Collaboration \\
\hline $\begin{array}{l}\text { U.S Department of } \\
\text { Commerce (2013) }\end{array}$ & The Innovative and Entrepreneurial University \\
\hline
\end{tabular}

Some of the highlights are: Boeing Company developed relationships with 300 universities and plan to shift their production to other countries.Intel established relationships with 150 universities in 34 countries.

\section{Questionnaire}

One questionnaire was developed to collect selected information from 146 faculty members who attended various faculty development programs over a period of Table -2: Quality Analysis of the Feedback

\section{Literature Survey}

The literature survey has focused on the current practices in pioneering universities of USA. These universities started refocusing on the quality of the InstituteGovernment-Industry due to emergence of competition from India and China. They have conducted research studies to protect their leadership. Selected contributions have presented in the Table-1 given below:

\begin{tabular}{|l|l|l|l|}
\hline Item & $\begin{array}{l}\text { No. of } \\
\text { positive } \\
\text { responses }\end{array}$ & $\begin{array}{l}\text { Percentage } \\
\text { order }\end{array}$ \\
\hline Colleges started testing works for government departments and local industries & 87 & 59.59 & 2 \\
\hline
\end{tabular}

three years (2008-2011). 20 key factors were selected to focus the expertise of the institutions in the southern region which has more number of engineering colleges and private deemed to be universities. Also the state technical universities have been established by the state governments and the engineering colleges have been disaffiliated from the liberal arts and science universities and affiliated to the state technical universities. The analyses of the feedback were presented in Table- 2 . 


\begin{tabular}{|c|c|c|c|}
\hline Developed websites for testing services and conducted open house for industries & 42 & 28.78 & 4 \\
\hline $\begin{array}{l}\text { Trained the senior faculty members in planning technical and financial proposals for } \\
\text { undertaking sponsored development projects }\end{array}$ & 38 & 26.03 & 5 \\
\hline $\begin{array}{l}\text { Established a dedicated consultancy center for undertaking sponsored development } \\
\text { works for industries }\end{array}$ & 27 & 18.49 & 7 \\
\hline Norms for sharing the project gains after meeting the project related expenditures & 98 & 67.12 & 1 \\
\hline Exclusive project related technical support staff & 32 & 21.91 & 6 \\
\hline Commissioned external experts for specific projects & 17 & 11.64 & 8 \\
\hline $\begin{array}{l}\text { Planned sponsored projects in collaboration with more than two engineering } \\
\text { departments in the same institute }\end{array}$ & 16 & 10.96 & 9 \\
\hline $\begin{array}{l}\text { Networked with other colleges in the southern region for bidding the sponsored } \\
\text { projects under MNCs }\end{array}$ & Nil & 0 & 16 \\
\hline $\begin{array}{l}\text { Networked with other colleges/ universities in the state for bidding for the sponsored } \\
\text { consultancy works under IDAs }\end{array}$ & Nil & 0 & 16 \\
\hline Networked with national laboratories/CSIR labs for consultancy works & 4 & 2.74 & 13 \\
\hline Established satellite consultancy centers in the industrial hubs/corridors & Nil & 0 & 16 \\
\hline $\begin{array}{l}\text { Successfully completed sponsored works costing above Rupees one hundred thousand } \\
\text { over a period of three years from a single agency/company/government department }\end{array}$ & 86 & 58.90 & 3 \\
\hline $\begin{array}{l}\text { Successfully completed sponsored projects costing above Rupees one million over a } \\
\text { period of three years under single agency }\end{array}$ & 16 & 10.96 & 9 \\
\hline $\begin{array}{l}\text { Successfully completed sponsored projects costing above Rupees } 10 \text { million over a } \\
\text { period of three years from IDA for one project authority }\end{array}$ & Nil & 0 & 16 \\
\hline $\begin{array}{l}\text { Administrative approval and facilitation for going global or planning to undertake } \\
\text { projects under IDAs }\end{array}$ & Nil & 0 & 16 \\
\hline $\begin{array}{l}\text { Academic Leadership and desired competencies for preparing high end projects under } \\
\text { IDAs }\end{array}$ & 5 & 3.42 & 12 \\
\hline Delegation and empowerment to plan high end global projects under IDAs & 3 & 2.05 & 14 \\
\hline Willingness to work with international consultancy projects & 3 & 2.05 & 14 \\
\hline Willingness to plan outreach programs for developing industry executives & 6 & 4.10 & 11 \\
\hline
\end{tabular}

The following points are synthesized from the above qualitative analysis:

\section{Significant areas in Industry-Academy-Government Partnership}

- Norms for sharing the project gains: $67.12 \%$

- Started testing services: $59.59 \%$

- Successfully completed sponsored works costing above Rupees

One hundred thousand over a period of three years: $58.90 \%$

\section{Initiatives in Industry-Academy-Government Partnership}

- Developing websites for testing services and conducted open houses: $28.78 \%$

- Trained the senior faculty members in technical and financial proposals: $26.03 \%$

- Exclusive project related technical staff: $21.91 \%$

Weak areas which require support
- Establishing dedicated consultancy centers

- Established satellite consultancy centers in the industrial corridors and hubs of the state

- Commissioning external consultants based on the project needs

- Networking with other engineering colleges and deemed universities

- Planning high end consultancy projects which require in depth competencies

\section{Areas where no work was started:}

- Networking with other colleges in the region for bidding projects

- For sponsored projects under MNCs

- Networking with other colleges in the region for bidding projects

- for sponsored projects

- Successfully completing sponsored projects costing above Rupees 10 million 
- over a period of three years from IDA for one project

\section{Barriers to overcome:}

- Tunnel vision on undertaking larger industry sponsored research and consultancy projects

- No delegation and over centralization of decision making

- No empowerment of high performers

- Traditional outlook of extension activities

\section{Institutional Development and Networking with the} National Labs and Technical Universities

The institutions could be facilitated to network with other universities, professional associations, and national laboratories through enlarged vision. This would assist the institute to plan technical working group meetings. The administrative barriers have to be minimized if possible eliminated. Networking also helps the faculty and students to interact on the real world problems.

\section{Establishing Satellite Consultancy Centers in the Industrial Hubs and Corridors}

The institutes which are located in rural areas need to establish satellite consultancy centers in the industrial hubs and major industrial corridors in the state. The administrative restrictions could be eliminated for better educational outcomes.

\section{Focused Faculty Development}

Many senior faculty members also need in-depth training in planning and designing consultancy projects based the terms and conditions (TOR) of the clients. Most of the projects depend on the success of similar projects already completed, internal revenue generated, key competencies of the resource persons. Hence, the institutes could plan appropriate faculty development programs in collaboration with high performing consultants under various projects.

\section{Formation of Consortium for bidding for the Projects under International Development Agencies (IDAs)}

Many institutes need sufficient number of high end faculty. Also projects which are very complex demand multidisciplinary teams with high end skills in planning, designing, developing prototypes, testing and improving the products. There is need for appropriate educational culture to form project based teams formed from a consortium of institutes. This calls for memorandum of understanding (MoU) with detailed responsibilities and ways of sharing the gains of the project. Such consortiums are there in the American universities through which ten or twelve universities jointly prepare the bid documents and negotiate under bilateral programs. Once, the projects are granted, the institutes share the work as per the agreed norms.

\section{Establishing Industry-Institute- Government- Partnership Centers in the Institutes and Units in the Industrial Hubs}

For undertaking Sponsored Research Programs and Projects, engineering colleges and state technical universities have to plan satellite research centers in various industrial corridors and hubs. Necessary funds could be sanctioned by the state or Ministry of Human Resource Development. Such centers would provide more facilities to a group of colleges. More collaboration among them would produce regional competitiveness.

\section{Facilitating National and Global Consultancy Programs by the Indian Consulates Abroad}

The International Development Agencies look for the consultants from the emerging countries to undertake many complex programs based on their earlier success. Indian Missions could gather information and pass them to the Ministry which could distribute them to the colleges and universities. The Ministry of Human Resource Development could take broader initiative in utilizing the available expertise of these institutes. Also there is an urgent need for revising the National Education Policy.

\section{Policy Enhancement}

Most of the institutes have Board of Governors headed by a well-known industrialists or scientists or academicians. The Boards could initiate and approvestrategic vision which could be generated by the faculty in consultation with All India Council for Technical Education (AICTE). The administrative barriers could be removed so that the performers could be facilitated to use their creative thinking, research capability and fearlessness. This would enable them to plan industry relevant graduate and 
postgraduate programs and research topics for dissertation and doctoral theses.

\section{Facilitating the Faculty for Undertaking the Multidisciplinary Programs and Sponsored Research}

At present, there are many restrictions and barriers to plan interdisciplinary and multidisciplinary graduate and postgraduate programs from national councils (AICTE) and commissions (UGC). However, by jointly planning and evaluating the draft programs with industrial associations, and the desired industry sponsorship would bring the need for such programs. Once industry approves the graduate programs by offering training and internship, the programs could be launched. The following are some of the examples:

Postgraduate program in Thermal Engineering was developed by NIT Trichy in collaboration with Bharath Heavy Electricals Limited (BHEL).

Postgraduate Program in Human Resource development for engineering graduates which would meet the demand for employee and executive development officers in technology oriented jobs and development of human capital in emerging technology.

Postgraduate Program in Construction Management could be well planned in collaboration with Construction Industry and Builders society.

Many CSIR laboratories started their won postgraduate programs in various branches so that these engineers could undertake advanced design and research .Postgraduate programs in aircraft design and manufacturingin collaboration with HAL and NAL

Automobile Engineering in collaboration with the Automobile Manufacturers

Curriculum development for industry relevant graduate and postgraduate programs is to be planned in close collaboration with companies in the industrial corridor and hubs.

\section{Role of External Consultants}

The institutes could co-opt appropriate external consultants with competencies on the project related activities. They could be from the national laboratories, other universities, government departments.

\section{Adjunct Faculty}

The institutes could employ adjunct faculty from industry, national labs and entrepreneurs to supplement the regular faculty to meet the needs of the students. They need to offer the courses on the current industrial development in product planning, design, analysis of performance tests and improvements.

\section{Faculty Development}

There is a need for assessing the needs of the faculty.In addition to training needs analyses, there is a need for job synthesis. The following areas could be considered for developing the faculty to improve the quality of engineering programs:

Modern trends and advances in industrial production.

Impact of information technology enabled design tools.

Assessmentof industrial needs in research and product planning is foremost impotant.

Planning Technical and Financial Proposals for consultancy projects based on the terms of reference (TOR).

Training the facultyand the students in the industries in state and the region have to be planned through consortium of institutes.

\section{Conclusions}

Engineering education has to develop more industry specific graduate and postgraduate programs to meet the requirements of modern industries. The faculty members have to be developed to plan to undertake industry sponsored consultancy projects, bid for the projects under international development agencies. The colleges could plan consortium for jointly plan, bid, negotiate and implement high end projects. The rural and semi-urban institutes have to establish satellite centers in the industrial hubs and corridors for undertaking consultancy projects. To overcome the shortage of expertise, the institutes could opt for project specific adjunct faculty. The faculty could be empowered to undertake high end industry sponsored research works. Based on the expertise gained, they can plan interdisciplinary and multidisciplinary programs in consultation with the companies in the industrial hubs and corridors. The institutes could realistically develop strategic plans and improve the academic environment. Such 
initiatives could assist the students also in planning industry relevant research works and ensure appropriate human capital.

\section{References}

Emily Abbott et al.(2011) "Five Essential elements of a Successful Twenty-First Century University Corporate Relation Program," Network of Academic Corporate Relations Officers Bench Marking Committee.

Julio A. Pertuze et al (2010)"Best Practices for IndustryUniversity Collaboration", MIT Sloan Management Review,51( 4) (Reprint No.51),

www.sloanreview.mit.edu

Katherine Chudoba, Mary Beth Watson and Kevin Crowston (2012) "Innovation in Academic- Industry Partnerships: Measuring Challenges to Effective Performance", TIM Submission ID 17445, Boston, MA

Mark L. Gorden"University Controlled or Owned Technology": The State of Commercialization and Recommendations, http://www.gbkeebaiigmenfeledpimamgkj/views/app.htm I

NACRO Writing Team and Benchmarking Committee (2011) "Five Essential Elements of a Successful TwentyFirst Century University Corporate Relations" Program Office of Innovation and Entrepreneurship Economic Development, Administration in consultation with National Advisory Council on Innovation and Entrepreneurship,USA

New York State University "Administrative ReEngineering- A Follow-up to John Sexton's Memo",http://www.nyu.edu/about/leadership-universityadministration/office-of-the-president/ office-of-

theexecutivepresdent/redirect/administration

Renu Khater (2013) "Forging Strategic Business Partnership to Develop the 21st Century Workforce, A Case Study of the University's Undergraduate petroleum Engineering Program", The Business-Higher Education Forum., www.bhef.com

Roger L. Geiger, Corporate-Sponsored Research at Penn State: Report to the Office of the vice President for Research, Center for the Study of Higher Education, the
Pennsylvania State University, http://www.ed.psu/cshe/wrking-papers/wp-1

Senate Task Force on University-Industry Partnerships"Principles and guidelines for Large Scale Collaborations between the University and industry, Government and Foundations, USA

UIDP Projects (2013)“10 Case Studies of High-Return University-Industry Collaborations"

U.S. Department of Commerce (2013)“The Innovative and entrepreneurial University",Higher Education, Innovations and Entrepreneurship in Focus, Office of Innovation and Entrepreneurship Development.

Short biography of the author: Dr. Thanikachalam Vedhathiri earned B.E (Civil Eng., 1968, Madras Univ.), M.Tech (Foundation Eng., 1970, IIT-Madras), Ph..D (Civil Eng., 1975, Madras Univ.), M.S., (IST, 1988, Indiana Univ., USA), FIGS, FIE, Former Fulbright Scholar, Program Executive-Continuing Education, Nodal Officer for World Bank Assisted Projects in Technician Education, Founder Professor for M.Tech (HRD), Consultancy projects under IDAs like ADB., UNDP., UNESCO and World Bankand Overseas Teachers and Executives Development Programs sponsored by IDAs and Government of India. Under his guidance 15 scholars have earned Ph.D in engineering education and another one submitted his thesis and two have submitted the synopses. He has published over 200 articles, monographs, video programs and conducted faculty development programs for the Polytechnics and Engineering Colleges since 1976. He has also conducted executive development programs for the corporates. 